\title{
Design of Savonius-Darrieus a Hybrid Wind Turbine
}

\author{
Fitria Hidayanti, Erna Kusuma Wati, Yohanes, Pudji Untoro
}

\begin{abstract}
Savonius wind turbine design use type two blades with a diameter of $15.5 \mathrm{~cm}$, a height of $10.9 \mathrm{~cm}$ and turbine weight of $51.3 \mathrm{~g}$. The Darrieus wind turbine design uses type three blades with dimensions $21.8 \mathrm{~cm} \times 8.7 \mathrm{~cm} \times 2.3 \mathrm{~cm}$. The weight of each blade is $51.3 \mathrm{~g}$ with the angle between the blades being $120^{\circ}$. The voltage of $2.5 \mathrm{~V}$ produced a minimum turbine rotation speed of $284.2 \mathrm{rpm}$ and a maximum of $296.0 \mathrm{rpm}$. When the voltage was increased to $5.0 \mathrm{~V}$, the minimum speed is $342.8 \mathrm{rpm}$ and a maximum speed of $366.4 \mathrm{rpm}$. When given a voltage of $7.5 \mathrm{~V}$, a minimum speed of $461.7 \mathrm{rpm}$ and a maximum of $481.3 \mathrm{rpm}$ were produced.
\end{abstract}

Keywords : hybrid wind turbine, turbine rotation, design, vertical axis, savonius, darrieus

\section{INTRODUCTION}

The most commonly used wind turbine is the Horizontal Axis Wind Turbine (HAWT) in which the axis of rotation is parallel to the ground. However, there is another type of wind turbine, the Vertical Axis Wind Turbine (VAWT) which is the focus of this study $[1,2]$.

VAWT has a number of advantages over HAWT, namely simple construction, VAWT can accept wind from all directions and VAWT works well in places with relatively low wind strength and constant wind [3, 4]. VAWT has two types of turbine configurations, i.e. the drag type where the wind turbine moves due to drag force (wind drag) against the wind captured by the blade and the type of lift where the wind turbine moves due to lift force (lift force) to the wind [5]. This research aims to design an efficient Hybrid VAWT.

Wind energy is an energy that can be used to drive turbines. A wind turbine is a system that functions to convert wind kinetic energy into mechanical energy on the turbine shaft. There are two types of wind turbines, namely Horizontal Axis Wind Turbine (HAWT) and Vertical Axis Wind Turbine (VAWT).

\section{Savonius and Darrieus Wind Turbines}

Savonius wind turbines are VAWT which the wind direction is ignored because the turbine will still rotate for all wind directions $[6,7]$. This wind turbine is ideal for use in

Revised Manuscript Received on March 13, 2020.

* Correspondence Author

Fitria Hidayanti*, Department of Engineering Physics, Universitas Nasional, Jakarta, Indonesia. Email: fitriahidayanti@gmail.com

Erna Kusuma Wati, Department of Engineering Physics, Universitas Nasional, Jakarta, Indonesia.

Yohanes, Department of Engineering Physics, Universitas Nasional, Jakarta, Indonesia.

Pudji Untoro, Department of Engineering Physics, Universitas Nasional, Jakarta, Indonesia.

(c) The Authors. Published by Blue Eyes Intelligence Engineering and Sciences Publication (BEIESP). This is an open access article under the CC BY-NC-ND license (http://creativecommons.org/licenses/by-nc-nd/4.0/) areas with erratic wind directions. However, Savonius wind turbines only have an efficiency of around $15 \%$. This means that only $15 \%$ of the wind energy that hits the turbine turns into mechanical turbine energy. Turbine speed cannot rotate faster than wind speed [8].

Darrieus wind turbines are VAWT can rotate faster than wind speeds up to several times $[9,10]$ due to Darrieus wind turbines produce smaller torque compared to Savonius wind turbines. This makes the Darrieus wind turbine more suitable to be used as an electric generator than the Savonius wind turbine.

\section{Hybrid Wind Turbines}

In the development of VAWT, Hybrid wind turbines are the latest VAWT [11]. A hybrid wind turbine is a combination of Savonius wind turbines and Darrieus wind turbines in one vertical axis. This turbine has two forces in its rotation, namely the drag force (drag force) of the Savonius wind turbine that functions as self-starting and lift force (lift force) blade of the Darrieus wind turbine which functions to accelerate the turbine rotation [12].

\section{MATERIALS AND METHOD}

Savonius wind turbine design uses type 2 blades with a diameter of $15.5 \mathrm{~cm}$, a height of $10.9 \mathrm{~cm}$ and turbine weight of $51.3 \mathrm{~g}$. The material used to make Savonius blade is aluminium cans, while for making Savonius plates is a canopy. Iron glue is used to glue the blade to the plate. At each plate, an $\mathrm{L}$ connection is installed which will be used to connect the Savonius wind turbine to the Darrieus wind turbine. L joints are made of modified aluminium cans (Fig. 1).

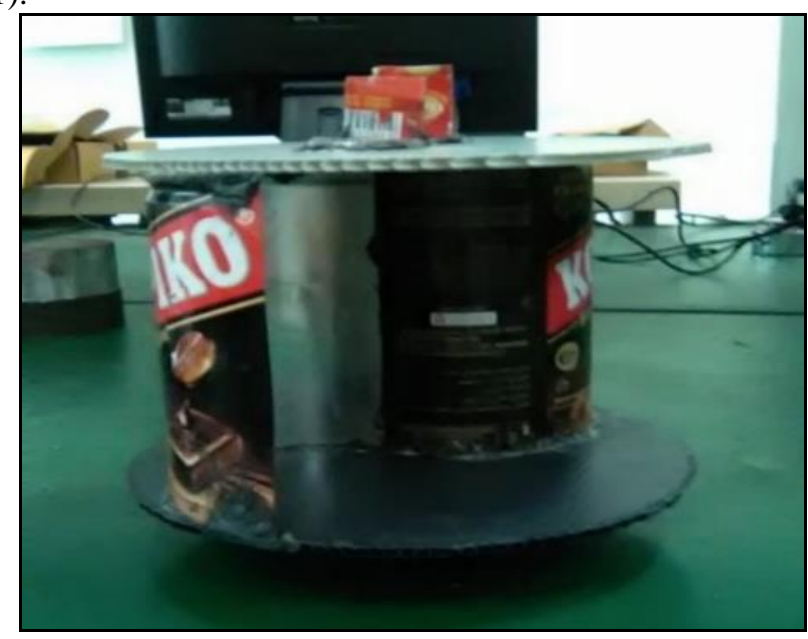

Fig. 1. Savonius Wind Turbine

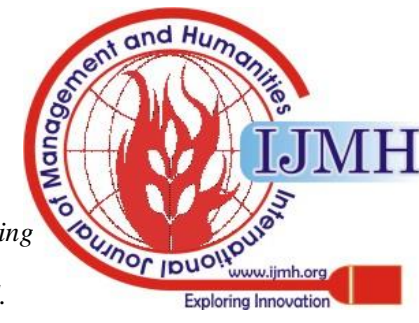




\section{Design of Savonius-Darrieus a Hybrid Wind Turbine}

\section{Design of Darrieus Wind Turbines}

The Darrieus wind turbine design uses type 3 blades with each blade having a length of $21.8 \mathrm{~cm}$, a width of $8.7 \mathrm{~cm}$, and a height of $2.3 \mathrm{~cm}$. The weight of each blade is $51.3 \mathrm{~g}$ where the frame was made using plywood boards, connected and coated with aluminium foil and paper. The three blades are connected using plywood boards and the angles formed between the blades are $120^{\circ}$. The total weight for a Darrieus wind turbine is $238.2 \mathrm{~g}$ (Fig. 2).

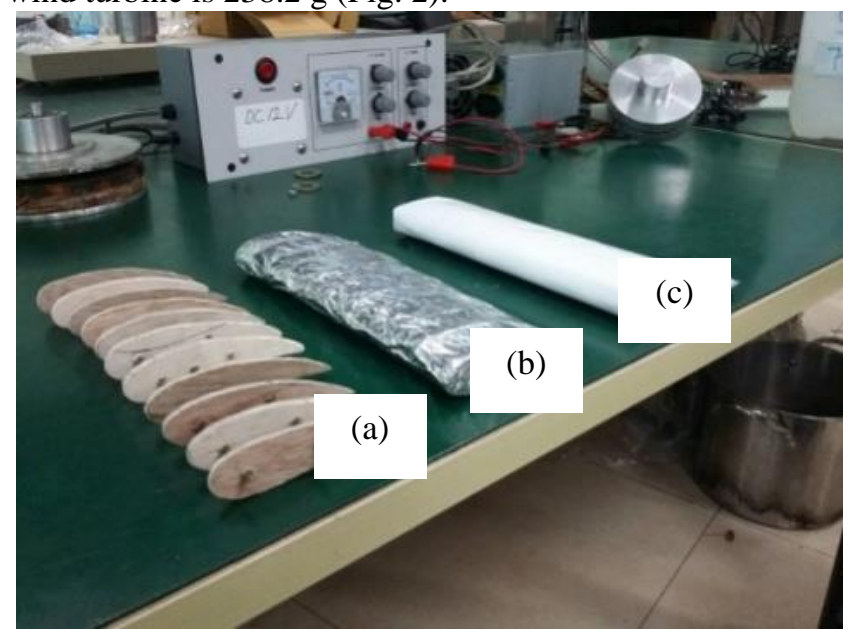

Fig. 2.Blade

(a) Initial Blade, (b) Blade after coated with aluminium foil, (c) Blade after coated with paper

The Darrieus wind turbine design uses type 3 blades with each blade having a length of $21.8 \mathrm{~cm}$, a width of $8.7 \mathrm{~cm}$, and height of $2.3 \mathrm{~cm}$. The weight of each blade is $51.3 \mathrm{~g}$ where the frame is made using plywood boards, connected and coated with aluminium foil and paper. The three blades were connected using plywood boards and the angles formed between the blades are $120^{\circ}$. The total weight for a Darrieus wind turbine is $238.2 \mathrm{~g}$ (Fig. 3 ).

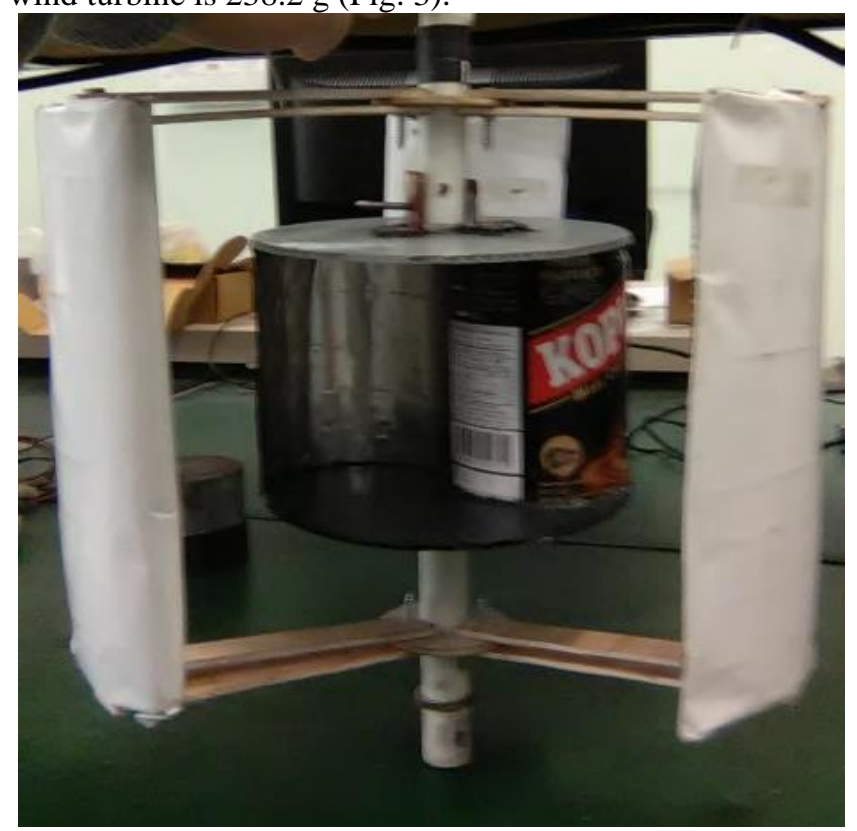

Fig. 3.Hybrid wind turbine (Savonius - Darrieus)

The hybrid wind turbine design used is a combination of two blades Savonius wind turbines and three blades Darrieus wind turbines with a diameter of $29.0 \mathrm{~cm}$. a height of $32.0 \mathrm{~cm}$ and turbine weight of $330.7 \mathrm{~g}$.

\section{Hybrid Wind Turbine Testing Procedure}

Tool testing was carried out in the following stages :

a. Install a hybrid wind turbine with a motorcycle dynamo that is connected to the power supply. Dinamo as a simulation of a hybrid motor wind turbine.

b. Install a hybrid wind turbine with a bicycle light dynamo. Dinamo acts as a hybrid wind turbine generator, installed at the top of the turbine.

c. The first test is testing the turbine rotation with an rpm meter.

d. The second test is testing the generator output voltage with a multimeter.

e. The input voltage of the power supply is varied $(2.5 \mathrm{~V} ; 5.0$ $\mathrm{V} ; 7.5 \mathrm{~V})$

\section{RESULTS AND DISCUSSION}

Based on the testing procedure, the results of testing the turbine speed using the rpm meter as Table 1.

Tabel 1. Research Data of Hybrid Wind Turbine

\begin{tabular}{|c|c|c|}
\hline $\begin{array}{c}\text { Power } \\
\text { Supply } \\
\text { Voltage } \\
\text { (V) }\end{array}$ & $\begin{array}{c}\text { Turbine Rotational } \\
\text { Speed (rpm) }\end{array}$ & $\begin{array}{c}\text { Turbine } \\
\text { Generator } \\
\text { Voltage (mV) }\end{array}$ \\
\hline \multirow{2}{*}{2.5} & 296.0 & \multirow{2}{*}{8} \\
\cline { 2 - 2 } & 284.2 & \multirow{2}{*}{35} \\
\cline { 2 - 2 } 5.0 & 366.4 & \multirow{2}{*}{40} \\
\hline \multirow{2}{*}{7.5} & 342.8 & \\
\cline { 2 - 2 }
\end{tabular}

From the results of research data obtained the relationship between turbine speed with the input voltage provided by the power supply. When given a voltage of $2.5 \mathrm{~V}$ produced a minimum turbine rotation speed of $284.2 \mathrm{rpm}$ and a maximum of $296.0 \mathrm{rpm}$. When the voltage is increased to $5 \mathrm{~V}$ the minimum speed is $342.8 \mathrm{rpm}$ and a maximum speed of $366.4 \mathrm{rpm}$. When given a voltage of $7.5 \mathrm{~V}$, a minimum speed of $461.7 \mathrm{rpm}$ and a maximum of $481.3 \mathrm{rpm}$ are produced.

\section{CONCLUSION}

The design of a hybrid wind turbine with the incorporation of a Savonius two blades wind turbine with a three blades Darrieus wind turbine has been successfully made. Hybrid wind turbines that have been designed and built on an experimental scale show quite good performance. From the results of experimental data in this study it can be concluded that with a further modification of this design, this Hybrid wind turbine is suitable for use as a small-scale wind power plant.

\section{ACKNOWLEDGMENT}

Thank you for Lembaga Penelitian dan Pengabdian kepada Masyarakat (LPPM) Universitas Nasional and my collegues in Faculty of Engineering and Science, Universitas Nasional.
Published By:

Blue Eyes Intelligence Engineering \& Sciences Publication

(c) Copyright: All rights reserved.

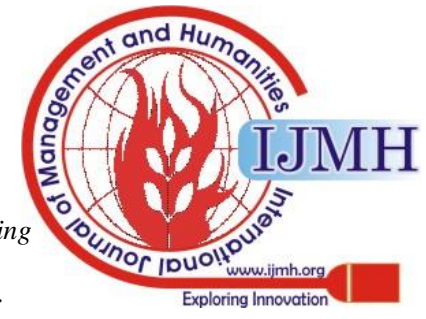




\section{REFERENCES}

1. Bhutta, M.M.A., et al., Vertical axis wind turbine-A review of various configurations and design techniques. Renewable and Sustainable Energy Reviews, 2012. 16(4): p. 1926-1939.

2. Dabiri, J.O., Potential order-of-magnitude enhancement of wind farm power density via counter-rotating vertical-axis wind turbine arrays. Journal of renewable and sustainable energy, 2011. 3(4): p. 043104.

3. Nobile, R., et al. Dynamic stall for a vertical axis wind turbine in a two-dimensional study. in World Renewable Energy Congress-Sweden; 8-13 May; 2011; Linköping; Sweden. 2011. Linköping University Electronic Press.

4. Li, Y., et al., Starting performance effect of a truncated-cone-shaped wind gathering device on small-scale straight-bladed vertical axis wind turbine. Energy conversion and management, 2018. 167: p. 70-80.

5. Thanigaivel, G., Design and analysis of drag and lift vertical axis wind turbine. J. Chem. Pharm. Sci., 2015. 7: p. 106-108.

6. Akwa, J.V., H.A. Vielmo, and A.P. Petry, A review on the performance of Savonius wind turbines. Renewable and sustainable energy reviews, 2012. 16(5): p. 3054-3064.

7. Kacprzak, K., G. Liskiewicz, and K. Sobczak, Numerical investigation of conventional and modified Savonius wind turbines. Renewable energy, 2013. 60: p. 578-585.

8. Jafarnejadsani, H., J. Pieper, and J. Ehlers, Adaptive control of a variable-speed variable-pitch wind turbine using radial-basis function neural network. IEEE transactions on control systems technology, 2013. 21(6): p. 2264-2272.

9. Balduzzi, F., et al., Critical issues in the CFD simulation of Darrieus wind turbines. Renewable Energy, 2016. 85: p. 419-435.

10. Lanzafame, R., S. Mauro, and M. Messina, 2D CFD modeling of $H$-Darrieus wind turbines using a transition turbulence model. Energy Procedia, 2014. 45(0): p. 131-140.

11. Debnath, S. and M. Saeedifard, A new hybrid modular multilevel converter for grid connection of large wind turbines. IEEE Transactions on Sustainable Energy, 2013. 4(4): p. 1051-1064.

12. 12. Abid, M., et al., Design, development and testing of a combined Savonius and Darrieus vertical axis wind turbine. Iranica Journal of Energy and Environment, 2015. 6(1): p. 1-4.

\section{AUTHORS PROFILE}

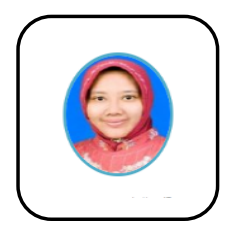

Fitria Hidayanti, Ph.D. candidate at Faculty of Engineering, University of Indonesia. She obtained her bachelor degree at Bandung Institute of Technology, Indonesia and master degree at University of Indonesia. Currently. She is an Assistant Professor at Engineering Physics Department, Universitas Nasional, Jakarta, Indonesia.

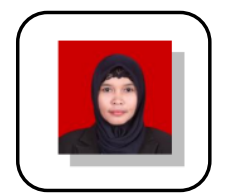

Erna Kusuma Wati, She obtained her bachelor degree in Physics Education from the Yogyakarta National University, Indonesia. She completed her master degree in Physics at Gadjah Mada University. Currently, she is an Assistant Professor at Universitas Nasional, Jakarta, Indonesia.

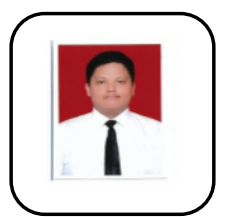

Yohanes, He obtained Bachelor Degree at Engineering Physics Department, Universitas Nasional, Jakarta, Indonesia.

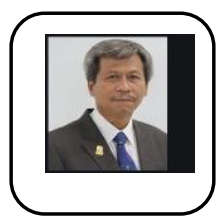

Pudji Untoro, He is Associate Professor at Surya University, Indonesia. 